\title{
What is SAID ABOUT'
}

THE

NORTH CAROLINA AGRICULTURAL

Experiment Station.

Opinions of the Press and the People.

\author{
Published by Order of the \\ Board of Agriculture.
}

RALEIGH :

P. M. Hale and Edwards, Brovghton \& Co., State Printers and Binders. 1880. 



\section{What is SAid ABOUT}

THE

NORTH CAROLINA AGRICULTURAL

Experiment Station.

Opinions of the Press and the People.

Published by Order of the

Board of Agriculture.

RAIEIGH :

P. M. HALE, AND EDWARDS, BROUGHTON \& CO.,

State Printers and Binders.

1580 . 


$$
\begin{aligned}
& \text { 11) z.zuange } \\
& \text { Univ of theth comolines } \\
& \text { OCT } 1 \% 193 \%
\end{aligned}
$$




\section{INTRODUCTION.}

At a recent meeting of the Board of Agriculture, the Chemist ras ordered to place in the hands of the Finance Committee such letters and newspapers as were on file at the Station criticising and commenting on its work. The Committee were instructed to make a few selcctions from the letters and to publish the same for distribution in the State. Acting upon these instructions, the Finance Committee respectfully submit the present pamphlet to the farmers of North Carolina, with the hope that it will tend to increase the usefulness of the Department of Agriculture.

The reasons which influenced the Board in ordering this publication will be readily understood. It is absolutely necessary to the usefulness of the Station that our farmers should have full confidence in it. To secure this confidence among the thousands who have had no opportunity of inspecting the work or testing its accuracy for themselves, is the reason for publishing the opinions of men who have had the opportmnity to judge of the value of the analyses, tests, \&c., or whose experience renders them competent to express an opinion.

It is the desire of the Board of Agriculture that the Station should continue to do much useful work for the farmers of our State, in whose interest it was established.

THOS. M. HOLT,

WM. H. CHEEK, Finance Committee.

Raleigh, N. C., Feb. 27th, 1850. 



\title{
Opinions of the Press and the People.
}

In a letter to President Battle, Gov. Jarvis writes as follows:

\author{
Executive Department, \\ Raleigh, N. C., Feb. 2, 1880.
}

Whatever may be the criticisms upon the Department of Agriculture, I believe it has done and is doing a good work for the Agricultural interests of the State. The protection it has given the farmer in the matter of worthless fertilizers through the Experiment Station at Chapel Hill, is worth, in my opinion, a hundred times all that has been spent. The fidelity of Col. Polk in collecting the samples of these fertilizers, and the skill and impartiality of Dr. Ledoux in analyzing them, entitles them both, if they had performed no other work, to the thanks of the farmer. I greatly regret losing Dr. Ledoux. His place will be hard to fill. We look mainly to you to get a good man for the position.

THOS. J. JARYIS.

\section{New Haven, CT., Dec. 16, 1879.}

I find in my travels through your State that you have the full confidence of the intelligent planters and dealers also, and I think you have reason to be proud of your successful attempt to establish a first class Experiment Station. I took particular pains to ascertain the feelings of the planters and heard not a word except in commendation of your work; 
also expressions of gratification at your prompt and satisfactory responses to letters they had written you for information, de.

\author{
H. L. Dudley, \\ President Quinnipiac Fertilizer Co.
}

Battleboro, N. C., Feb. 12, 1850.

I have just seen and read your "Annual Report of N. C. Experiment Station" for 1879, and have obtained much knowledge of commercial fertilizer's of which I have heretofore been much in the dark-a condition in which you will find many farmers all over the land. I have bought guanos and chemicals for years, at random, simply on testimony of agents who offered them for sale. Now I think I know more what I am buying, and by the analysis I am enabled to secure the fertilizers most suited to my land.

JoHN D. BUt.TOCK.

ENDERLy STOCK Farm, Charlotte, Feb. $16 t h, 1880$.

The Agricultural Experiment Station has already accomplished a great and beneficial work for the agriculturists of our State, and, if its future is not blighted by hostile legislation, it is destined to become a power of itself sufficient to protect us from those who deal in fraudulent fertilizers, chemicals, seeds, itc. The Station simply turns the light upon a fraudulent article so that he who runs may read: "Fraud! fraud!" and if there be any so blind that he will not see, he deserves to plant his crop "upon the sand." 
I hope the Station may continue its great and good work and I regret that "our Pioneer" has been called to other tields.

S. B. AlexANDER.

Bostox, Mass., Dec. 24, 1879.

Many thanks for your Inmual Report. It is a most excellent document, and did it not contain anything but your table of Fertilizers, the State might well afford to pay fol the expenses of your department.

- Maremale P. Wimeng.

White IIal, Ky., Jan. 9, 1880.

Your Report for 1879 was duly received and read with yreat interest. We just begin to realize the idea that agriculture as a science and an art is even now in its infancy, and that there is room in it for the ablest minds. Wishing you continued success, I an truly,

Cassius M. Clay.

Raverna, (Ohio, Dec. 30, 1879.

It is a work (the Report) that I shall take great interest in reading, and being President of both the Agricultural and Horticultural Societies of this county, I shall endeavor to have members of both Societies derive information from the same.

Horace G. Beebe. 
Lockville, N. C., Sept. 12, 1879.

I am deeply interested in your work, and am glad you are making a success.

J. H. WissLer.

\author{
Lafayette College, \\ Euston, Pa., Sept. 19, 1879.
}

It (the Report) contains much valuable information and should promote the interests of agriculture in other States as well as in North Carolina.

$$
\text { Trrall Green, (Prof.) }
$$

$$
\text { Washingtox, D. C., Sept. 20, } 1879 .
$$

You are doing a vast amount of excellent work, and I congratulate the people of North Carolina that they are pushing ahead so rapidly in the good work.

Peter Collier, Chemist U. S. Dept. of Agriculture.

Raleigh, N. C., Sept. 22, 1879.

Accept my thanks for a copy of your very interesting and instructive Report of the Experiment Station for the cur. rent year. Upon its receipt I commenced its perusal, and found the matter therein embraced treated in so practical 
and attractive a style, that I was unable to lay it aside until I had given it a full examination.

WM. R. Cox, (Judge).

$$
\text { Warrenton, N. C., Sept. 20, } 1579 .
$$

Please accept my thanks for the valuable record of your invaluable Station received a few days ago with your compliments.

W. J. WHite.

University of Rochester, Sept. 15.

You have placed me under special obligations in kindly sending me a copy of your excellent report. Such work as you are doing must prove of incstimable value to your State I am sorry that the State of New York is not sufficiently advenced to enable me to reciprocate your favor in kind.

\section{A. A. Lattimore,} Professor of Chemistry.

\section{Harrisburg, PA., Sept. 24, 1879.}

I am much interested in your work and I trust that the farmers of North Carolina will fully appreciate what is being done in their behalf. You have settled the value of "soluble silica" in a most satisfactory manner.

Andrew S. McCreath, Chemist Penn. Geol. Survey. 


\section{New York, N. Y., Nov. 12, 1879.}

I regard it as a model Report. Especially is it valuable to farmers for the practical manner in which it imparts information.

William Fullerton, (Judge).

Charleston, S. C., Feb. 14, 1880.

Accept my thanks for a copy of your "Annual Report of the N. C. Experiment Station," a work which reflects much credit upon the author. I have carefully looked through its pages, and find everywhere the marks of conscientious labor directed by scientific skill.

$$
\text { C. U. Shepard, Sr. }
$$

\section{Peekskill, N. Y., Oct. 4, 1879.}

Your Report for 1879 to hand. Accept my best thanks for same. You seem to have done an immense amount of work.

A. H. Elliott, Chemist.

Middletown, Conn.

Accept thanks for your very excellent Report for 1879 . Am glad to see evidence of so much activity and useful wrork.

W. O. Atтwater, Prof. of Chemistry. 
Brooklys, N. Y., Oct. 10, 1879.

I am sure your publication will please and instruct me very much; and as for the great value of your undertaking, the purpose of your Institution, its present and future pos. sibilities, there seems to be an unlimited field for conferriny benefits-yea, great blessings upon your own and other States. I hope that before many years pass, all the States will have Experiment Stations endowed with fully as mueh limit and authority as your Establishment seems to have.

Samuel B. Rice.

\section{Pinlad delihia, P.A., Sept. 6, 1879.}

I have looked through it [the Report] and found it to be nnexpectedly interesting and valuable. I was espeeially pleaser with your comparative trials of Popplein's Silicated Phosphate. I congratulate you upon the adinirable eharacter of your work.

WM. H. WAHL, Editor Engineering and Mining Journal.

New York, N. Y., Sept. 17, 1879.

You must have done a "pile" of work since your Directorship began in North Carolina.

Chas. M. Stillweli, Chemist. 
Littleton, N. C., Sept. 12, 1879.

Will you do me the kindness to send me a copy of the Annual Report of the North Carolina Experiment Station for 1879? I know of but one in this vicinity and that is esteemed very highly; and it is impossible for all to read that one.

W. F. Young.

\section{New ILaven, C'т., July 10, 1879.}

The samples of Cow Pea are received. They are acceptable as illustrating a crop of so much value to Southern Agriculture. I shall be glad to receive your Report, and have none but pleasant anticipation in its perusal. I fully appreciate your difficulties in conducting the Experiment Station at Chapel Hill; and, so far as I am am able to judge, you have done wisely and well. I assure you of my hearty sympathy and best wishes. Any reciprocation of your kindness in supplying me with these samples, that you can suggest, it would give me pleasure to make.

S. W. Johnson, Director Ct. Experiment Station.

Tarboro, N. C., Sept. 25, 1879.

I thank you for your manly defence of the Station at Chapel Hill. I am sure the Eastern portion of North Carolina are pleased with the Station under your management.

J. R. Thigpen. 
Poughreepsie, N. Y., Jan. 13, $18 S 0$.

The Annual Report of the North Carolina Agricultural Experiment Station, for 1879 , is a document that will be of great service to the community, whether agrarian or otherwise. Happily, our people almost throughout the Union, are waking up to the importance of these interests. Until I had the pleasure of hearing your lecture at the Metropolitan Hotel in New York, and reading this Report, I had no idea of the enormous production of adulterated seeds. Our Legislature, in times past, gave a cursory, inadequate attention to the subject, but very little practical good has resulted therefrom. The article, too, on mineral and well water, will, I think, open the eyes of many.

Ronert SANFORD.

\section{[HALE'S WEEKLY.]}

Now is the time when farmers wish to know what they buy in fertilizers, and, of course, Dr. Ledoux's analyses of those for sale in North Carolina are printed for the benefit of readers of Ilale's Weekly. They will be found among our "Farm and Garden Notes." The license tax paid on these fertilizers by their manufacturers has supported the Agricultural Department without having taken a dollar, directly or indirectly, from the pocket of any North Carolina taxpayer, unless he were also a fertilizer manufacturer. Before the Department was established 107 brands of fertilizers were sold in North Carolina. Of these, as we had occasion to note when urging the Agricultural bill before the Legislature of 1876 -'77, some were so worthless that they were re-shipped here from Georgia, which had its Department in operation and would not allow them to be sold there; one of them of large sale here being four-fifths sand. The license 
tax and the chemical analysis have driven out the worthless article, thus protecting lonest dealers against fraudulent man ufacturers, while the benefit to the farmer has been very great. ThE FERTILIzERS ARE MUCH BeTtER AND THEIR PRICES MATERIALLY LOWER. They are sold here just as cheaply as in Georgia, which has, as we have, a license tax, and as in Virginia and South Carolina which have not. One manufacturer tried to advance prices when the Department was established, but soon learned from the good people of Pamlico, upon whom the experiment was made, that it was useless. So we think that our friend of the Elizabeth City Economist is in error in saying that "the fertilizer manufacturers advanced $\$ 50,500, \$ 20,500$ ?) for the support of the Agricultural Department, but they get it back from the farmers, of course, and as they admit." If they "admit" such a thing it is doubtless in the hope of dissatisfying the farmer and inducing the repeal of a law which they fought long and bitterly before and after its passage, and in and out of the courts. THERE IS No GETTING AROUND THE THREE WELLCNOWN FACTS: THAT THE MANUFACTURERS PAY THE $\$ 500$ TAX, THAT THEY MAKE BETTER GOODS THAN EVER BEFORE, AND THAT THEY SELI THEM AT LOWER PRICES.

Connecticyt Experment Station, New Haven, Ct., Dec. 27, 1879.

My Dear Dr. Ledoux: * * * I should have scarcely dared undertaken to direct the Experiment Station here, had I not been able to get Drs. Jenkins and Armsby, who had special training in the Laboratory of the Scientific School for two years, then worked in my private Laboratory for a year, and afterwards a year in Europe, and a year more in this country, one at Middletown, the other at Rutgers' Scientific School. They came to me each with five year 
special training - none too much for the work they have to do, which is very responsible, * * for, as you know, we have but half-a-dozen schools in the country-I might say not half a dozen-where young men are trained thoroughly as chemists, and of those who graduate from them, not 10 per cent can be trusted to make a fertilizeranalysis without further drilling.

Yours very truly,

S. W. JoHNSON.

\section{JoHns-Hopkins UnHersity, \\ Baltimore, Jan. 5, $18 \mathrm{S0}$.}

Prof. A. R. Ledoux:

Dear Sir-I was glad to learn that you had decided to take Mr. Mager for your assistant, for I know that you will have a thoroughly competent man. The more experience I have in chemical work, the more the conviction is forced upon me that a thoroughly reliable, conscientious analyst is a very rare thing. This is, to a great extent, due to the weakness of human nature, but also, particularly in this country, to the inefficient character of the training to which students of chemistry are subjected. I do not think it is possible to make a thorough analyst, even out of good material, in. less than two years of solid laboratory work. As you know, there are few, if any, institutions in this country, in which this amount of time is devoted, or can well be devoted to chemistry. In the colleges, which are intended to give gencral training rather than speeial, to devote enough time to chemistry to make an analyst would be worse than absurd-it would be next to criminal. Fortunately, this view prevails pretty generally, so that graduates of colleges are never, as far as my experience goes, thorough or even tolerable analysts. At most, such graduates have a weak smattering of the subject 
of analytical chemistry, which would be of very little value in a responsible situation. For the kind of work in which you are engaged reliable assistants form, of course, one of the chief conditions of success. I am sure that in Mr. Mager you have a man of just the right stamp. He has worked with Fresenius at Wiesbaden, to begin with, and then he has worked for the past two years and a half uninterruptedly in my laboratory, where I have had daily opportunity to judge of his ability and other qualities. He has been engaged also for some months as my private assistant in car. rying on an investigation requiring the greatest delicacy of manipulation, and this work he has done to my entire satisfaction. I peat to you here the most cordial recommen. dation of him, in complete confidence that you will not be disappointed.

In conclusion, I only regret that there was not a vacant place among my assistants, which would perhaps have enabled me to keep Mr. Mager here, where I should very much like to have him.

Yours very truly,

Ira Remsen, Prof. Chemistry.

\author{
Wilmington Farm, \\ Henderson, N. C., Feb. 16, 1850.
}

Dr. A. R. Ledoux:

Dcar Sir-In my opinion, no country stands more in need of such an institution [as the Experiment Station] than North Carolina.

Having recently arrived here from England, I found the mode of farming very different from what it is there. Here it seems to be the method to crop the land as long as it will produce a crop, without any return to the soil, which must ultimately prove to be very destructive, if not ruinous. It 
is something new to an Englishman to see "worn-out" land, but such was the kind of land that I had the misfortune to purchase. By practicing the English system of cultivation, and by the very lind and able instruction I have from time to time reccived from you, I an slowly recuperating a small portion of my three hundred acre farm. I feel glad that the Goverument of this State has called into existence such an institution as the one of which you arc the manager. It is a safe authority to which we unscientific farmers can aplly for instruction in the pursuit of our calling.

It secms that the time las come when the occupation of tilling the soil is no longer to be carried on in a state of drudgery. Science has nobly come to our aid to assist us in the divinely instituted and most scientific calling man has ever pursued.

I hard occasion to state to the Honorable Board of Agriculture, a short time ago, that the Experiment Station not only throus around the farmer a safe-guard, protecting lizin from the unprincipled manufacturer of spurious fertilizers, but also leads him on in the sublime path of scientific agriculture.

Very respectfully yours,

R. Marston.

(Extract from Gov. Vance's Annual Message, Jan. 1, 1879.)

I call your attention to the report of Dr Ledoux, Director of the Fertilizer Control Station. It is gratifying in the extreme. You will perceive, that the quality of the Fertilizers sold in the State has steadily improved, and the market value of the improvement amounts to more than $\$ 100,000$ in two years. This is caused obviously by the fact that, knowing their wares were to be subject to a rigid scientific test, the dealers were careful to make them come up to the mark, and many others have quit the market altogether. 
(Wilmington Review, September, 1879.)

Agricultural Report.

We have received the "Anuual Report of the North Carolina Agricultural Experiment Station for 1879." The work comprises about 200 pages and is compiled by Prof. A. R. Ledoux, the State Chemist, by direction of the State Board of Agriculture. The book shows the workings of the Experiment Station at Chapel Hill, which is under the immediate supervision of Prof. Ledoux. It contains many valuable formulas for fertilizers, indicating those which are best for special crops. This is the first Ammal Report, and it is a source of pride to think that the entire work is in all its completeness a North Carolina production, and even the paper upon which it is printed was manufactured within the confines of the State.

(Mrs. C. P. Spencer, in the Chapel Hill Ledger.)

DR. LEDOUX's Report.

This pamphlet contains about 200 pages, is well printed, on good paper, and presents altogether a creditable appearance; the whole work, paper, printing, binding, drawings, \&c., being entirely a North Carolina production. It gives a complete review of two years work of the Agricultural Experiment Station at this place under Dr. Ledoux's charge, and if any one in the State is disposed to find fault with this department of the Agricultural Board, now is their time to take it up, scrutinize it carefully and state their grievance.

One charge at least against the officials of this Station cannot be made, namely: that they do not earn their salaries. The laws regulating the State Board of Agriculture require a great amount of work from this Station. It is ex- 
pected not only to analyze and report upon fertilizers, seeds, soils, marls, minerals, waters, crops and all sorts of experiments in field and domestic industry, and carry on a very large and increasing correspondence in relation to this work, but is required also to make all analyses for the State Creological Survey, for the State Board of Health, and for all cases of suspected poisoning. The objects of the Station becoming generally understood and the attention of business men and farmers being fixed upon it, the work and correspondence increased in the first year so that Dr. Ledoux was compelled to employ two assistants, and in the second year a third, so that there are now four gentlemen who give their whole time, often working far into the night when the work is pressing. And if any grumbler should think that analyzing fertilizers and the like is pleasant work, he should by all means come and try it.

In the two years existence of the Station three luundred and seventy-eight analyses have been made-comprising not only fertilizers, soils, ores, mineral waters, \&c., but seed tests, pine straw, drugs, beets, ite. The list presented, am the samples of correspondence given in connection are instructive, showing the range of inquiry and present de. mands of our agrieultural population. In one year Dr. Ledoux has written or dictated to his Secretary replies to 1,924 letters of inquiry. IIow to make vinegar? How to prepare bones for manure? What fertilizer to buy? How to plow for cotton? How to restore gray hair? What grasses are these? What insects? How to cultivate beets? What about mica mining? What about kerosene? What about sassafras oil? One would suppose Dr. Ledoux had opened a general intelligence office. It shows that our pen. ple are waking up. A spirit of inquiry is a revival spirit.

The Report gives formule and directions for composting; results of a few field experiments made with fertilizers furnished for the purpose to some half dozen Orange county farmers who sent in their reports; details of sugar-beet 
raising; of the cow-pea and its value; of cotton seed; of certain marls and nineral waters, \&c., \&c.

We found it all good and valuable reading, evidencing a practical mind, and a great share of plain, invaluable com. mon sense in the accomplished and excellent gentleman at the head of the Station. IVe feel sure that Dr. Ledoux is a great acquisition to the working force of the State; a man whose scientific acquirements and general fitness for his office are equalled by the prudence, good sense and amia. bility that have characterized him since his first coming amongst us.

[Statesville Landmark, September, 1879.]

We do not wish to be understood as being opposed to the Experiment Station: far from it. We have always been one of its most ardent friends and warmest supporter's. The Landmark has before pronounced this Station "the cloak that protects the farmer from fraud." And we believe that its head, Prof. Ledoux, is the "right man in the right place," a gentleman, a scholar and a scientist of the first order. His promptattention to duties and the skillful management of his department have endeared him to the people of his adopted State, especially the farmers.

\section{[Raleigh Observer.]}

The following we clip from the American Agriculturist. It should be a matter of pride to our people that in the midst of so much abuse of all that is Southern, a Northern journal will hold us up as an example worthy of imitation by other States, and accord to any of our State departments such hearty praise as we find below :

"Dr. A. R. Ledoux, chemist in charge of the North Car- 
olina Experiment Station, has just sent out a report of the investigations for the past year. The examination of seeds as to their purity has revealed some striking mixtures, the Dodder seed, for example, makes up a good part of some clover seed. The treatment of the velvet grass (Holcus lanctus) showing that this geverally concluded worthless grass is of merit as a renovator of wom out lands in the Southern States, has already been noticed by us, and is of real value. An analysis of the cow pea of the Sonthern States supplies what has long been needcd, and gives information that can be found nowhere else. The last third of the report is devoted to the analyses of fertilizers, which have done much to free the market of worthless brands, and raise the best fertilizers to their proper place. This portion of the work of the Experiment Station is perhaps that in which its utility is more directly manifest than in any other ; for it must have alicady saved large sums to the faimers of the State, und will save still more in the future. North ('wrolina has a right to be proud of the advenced position she has taken in agricultural matters, and may already be cited as an example to other states. It would be of untold benefit if every intelliyent furmer in the stute could have this Report and sturly its teachings."

[Hale's Weekly.]

At the last metting of Pomona Grange, of Cabarrus county, the following resolution was unanimously adopted: "That we regard the establishment of the Department of Agriculture of North Carolina of great benefit to the farmers of the State, that we hope the Legislature will foster it, and that we have entire confidence in Col. L. L. Polk as our Commissioner of Agriculture, and in Prof. A. R. Ledoux as our State Chemist." This is an honest and outspoken expression of the feelings of Pomona Grange, which they ask the press of the State to publish. 


\section{Pittsboro, N. C., Sept. 13, 1879.}

Dr. A. R. Ledoux:

Dear Sir-I am greatly obliged to you for the "Report of the Agricultural Experiment Station." It is both interesting and valuable, and I heartily commend the ability and skill which you have exhibited in your most laborious po. sition. The Station is doing a great good, and I consider it even more than the right arm of the Agricultural Department.

A. H. Merritt.

Henderson, N. C., Sept. 21, 1879.

1)T. Ledoux :

Den Sir-I duly received the report of the N. C. Experiment Station, for which please accept my sincere thanks. Its valuable contents must prove highly beneficial to those who are trying to recuperate the worn out soils of North Carolina. I am proud to becone a citizen of a country that both sees and feels the necessity of advancing its agricultural interests by the establishment of such an institution.

R. Marston.

NoTE-Mr. Marston iz an Englishman by birth. 
Report of the North Carolixa Experinent Station.

[The Rural Messenger, Petershurg, Va.]

The first Annual Report of the Director of the North Car. olina Experiment. Station has lately been received. anrl we deem it proper to extend it at least a passing notice. In the compass of about 200 pagres Professor Ledoux has condensed a lirge amount of information pertaining to his State that camnot fail to be of value to every farmer who will give it pernsal. Among much otler nuatter of an interesting and utilitarian character, we find papers on composting, the sugar beet, analysis of pine straw, the cow pea, cotton seed, marls, mineral and well waters, minerals and ores, soils, chemicals and fertilizers, and from which stores of information may be gleaned for the practical farmer. Considering the youth of this station, much work calculated to advance acricultural art has been done, and we camot but regard North Carolina as fortunate in laving a corps of such efficient and industrious toilers in the grand work of furthering scientific farming, or farming on scientific principles. The Report is intended to be useful to farmers, and is written in a style suited to the comprehension of the poorest educated among them. This is important. The work of the Station is for the instruction and benefit of the actual bread producers of the State. No calling more needs the aid of thinking men; no calling needs more the benefits to be rerived from a division of labor. The field is too broad-the details are too multitudinous for any one man or mind to master them all; and we rejoice that the farmers of our sister State will, or may if they choose, share in the benefits to be derived from the labors of such men as Ledoux, Kerr, Battle, Holt, Thigpen and others.

The history of the North Carolina Experiment Station is an interesting one. The expenses of the Station, amounting 
to $\$ 7,670$ in two years, costs the farmers and the tax-payers of the State not one cent-being met by a license tax imposed on the manufacturers and sellers of fertilizers. The income of the State Department of Agriculture from this source is about $\$ 15,000$ per annum, of which the Station receives say $\$ 4,000$ jearly. And yet many people and some papers in the State have seen fit to criticise adrersely some of the work of the Station! And that, too, while it has only been able, in the brief period of its existence, to get ready for work. We are not the champion of the Station, and have no interest therein, except what we may feel for the improvement of agriculture everywhere, but we must beallowed to say that, in our judgment, such persons and journals would do their State a greater service by giving the workers in the Experiment Station that moral encouragement and support they stand in need of, and without which it must be a failure at last. Instead of crying it down, or searching for Haws with microscopic glasses, they should try to build it up-to nake it better. But there are always prophets of evil everywhere. Of the twelve sent to view the promised land but two brought back a favorable report. Notwithstanding, Israel went up and possessed the land at last. We rejoice to know, however, that more than two have brought a good report of the N. C. Agricultural Station.

But one must read the report, or have copious extracts from it, in order to have an intelligent understunding of what has been done; and for such extracts we have at present no room. We do not mean to spare the shears, however, and will give several before long. There is information here that ought to have extensive circulation; and having hundreds of subscribers in that State, we reckon we shall be doing them valuable service by quoting liberally from this report. We promise to do so, and save ourself a longer notice here. But let all who can get a copy and read it entire. The influence of such publications is always for good, and under it we look for rapid advance in the intelligence, thoroughness, and results of North Carolina farming. 
(Raleigh News.)

The Expernant Station Exposes a Humbug.

Under the head of "Sundry Humbugs," we find the following in the last number of the American Agriculturist:

"Among the many swindles that are intended especially for the 'benefit' of farmer's is 'The Vitative Compound,' which came to us some time ago, with the most remarkable claims. It is soli by one Bingham, of Pennsylvania, and is claimed to be patented by one Waugaman. We shall presently show this name is not the ouly gammon that there is about it. It is sold in boxes, holding about two ounees, for $\$ 1.00$, and (heap at that when we consider what it is claimed it will do. We are told that the stuff "is purcly chentical in its character and effects, contains, in a cundensed form, those ingredients so gencrally deficient in the soil (we should hope they might be!) and yet so esserstial to the immediate and cortain germination of the seed, and the vigorous and rapid growth of the plant.' All sorts of claims, 'more vigorous and rapid growth,' \&c., \&c., are made, but the claim that struck us most reads: 'It is applied directly to the seed, and not scattered broadcast, as many fertilizers are.' It is said that Liebig once predicted the time when the manure for a whole field cunld be carried in the rost pocket, but here we don't manure the field at all. We go to head. quarters, and manure the seed just as the boy Franklin proposed that his father say grace over the whole barrel of pork. Then, so very 'vitative' is the stuff, that we learn that it will not only protect the seed, but 'the shoot, against wireworms, and grubs.' So powerful the stuff that we wonder any box could hold it. We, with proper care, laid the box aside for further examination, and impossible as it may seem, it was actually forgotten. But this compound was so 'vitative' that it turned up in North Carolina, and our friend, Professor A. I. Ledoux, the State Chemist, made it 
show its 'purely chemical character' in the 'twinkling of a gally-pot.' 'This 'Titative Compound,' according to Professor Ledoux, contains not one fertilizing ingred ient, but is a miserable mixture of sugar of lead and white vitroil!acetate of lead and sulphate of zine!-and the wonderful Wra gammon, who is said to have patented it, didn't know enough about chemical compounds to be aware that these two salts wonld decompose one another, so that, practically, the seed would be wetted with a little acetate of zinc! The stuff cost about four cents, and sold for a dollar, which might be called a 'living profit.' 'The North Carolina Experiment Station has done a very good thing in exposing this humbug, and we thank it for the anaysis of the "Vitative Compound.'"

[Correspondence of the Farmer and Mechanic.]

TAX ON FERTILIZERS.

I have been asked by one of the committce appointed by the State Agricultural Society to inquire into the views of the farmers on the advisability of the fertilizer tax, and to furnish the readers of the Famer and Mechanic with the result of my own observations. This request was made, inasmuch as I have frequent opportunities of intercourse with farmers in the counties of Warren, Franklin, Granville, Halifax, Edgecombe, Nash and Wilson. I take pleasure in stating that I have heard absolutely no complaint of the tax from any; while on the other hand, those who know anything of the law and of the operations of the Department of Agriculture, are unanimous in their approbation of both. They understand very well that the tax is no burden upon themselves, but on the contrary supports the fertilizer control station, from which they derive great benefit. I am giving the views of intelligent farmers when I say that the 
work of Dr. Ledoux is an honor and safe-guard to the agriculture of the State. Surely, the Old North State is no longer Rip Van Winkle, in this respect at least, since she and Connecticut are the only States in the Union which have Control stations. The analyses of Dr. Ledoux are of incalculable benefit to the farmer, since there is obviously no other way for the farmer to asecrtain the value of a fertilizer. But for analysis they may be imposed upon to any extent. To ascertain the value of a manure by its "Dehaviour in the fich" is rather a costly experiment for the farmer. Should it prove worthles, he loses both his money and his proposed profit for a whole year, and under the old system he had no redress. His only resource was to repeat the experiment with some other brand, and meet, perhaps, witl the same results.

The intelligent farmer smiled grimly, but with placid satisfaction, when Col. Ott hastily assailed the department and "Mr." Ledoux. He neeled no other explanation of the wrath of the Suthem Fertilizing Comprany, and no other endorsement of the department, than the fact of a discrepancy of $\$ 15$ to $\$ 20$ between the selling price of the fertilizer and its commerecal value as calculated from analysis. Now, every dealer must guarantee the constituents of the brand he puts upon the market, and an unscrupulous trarler stands in wholesome awe of the station. We have only to comlare Dr. Ledoux's analyses of the same brands for 1877 and 1878 to find a marked improvement in some of them. Heretofore the farmer felt distrustful that a hrand would deteriorate after having once established a reputation hy its "behaviour in the ficld."

Even on the part of strictly lionest dealers there is often a disposition to exact too large a profit, and large profits on fertilizers the present price of farm products will not justify.

I state the opinion of all intelligent farmers when I repeat that the State never legislated so wisely as when it imposed this tax for the support of the Department of Agriculture, 
and especially the Fertilizer Control Station. Let the farmer avail himself of its proffered advantages. Let him be careful how he handles articles which hare not been analyzed by Dr. Ledoux. At very small expense to himself, he can detcrmine whether he is paying for dirt, or for pure chemicals and active fertilizers. The writer not iong since received from Chapel Hill an analysis showing $84.03^{\circ}$ of muriate of potash in an article of German potash salts and guaranteed to contain $83^{\circ}$. This was very satisfactory, both to user and dealer. It is a satisfaction all may enjoy who will--just so long as the law stands unrepealed.

John W. Primrose.

(American Agriculturist, 1878.)

North Carolina is having a grood work done in its Agricultural Department by Dr. Ledoux, its chemist, in the important fertilizer question. II is labors have tended to place the manufacture and trade on a reliable basis, which means mucl when it is considered that about one million dollars' worth of fertilizers are sold and used in that State every year. We understand that preparations are now being made for more extensive experimental work and investigation under the anspices of the Department, and that an excellent assistant chemist, Mr. George Warnecke, who first came from Germany by invitation to the Connecticut Aorricultural Experiment Station at Middletown, has already been engaged. 
Report of the "Commitee on the Working of the Fertilizer tax" to the Executive Conmittee of the N. C. Agricultural Soctetry.

Hon. Thos. M. Holt, President N. C. Agricultural Socicty :

SrR-The conmittee to whom was referred by your honorable hody the following resolution, viz:

" liesolved, That a committee of five farmers be appointer to gather information from the farmers of the State in regard to the working of the tax on fertilizers, and that such committee be instructed to report to our Executive Committee before the first of December next; such report to be furnished the press of the state for publication-

Respectfully report that they have made cxtensive inquiries among the representative farmers of all parts of the State, and find the almost unanimous opinion to be, that the tax on fertilizers has heen productive of great benefit to the agricultural classes in several particulars:

1st. The andysis of the fertitizers used in the State, and the publication of the results of such analysis, enable farmers to form a more intelligent opinion as to what fertilisers are necded for their soils and what clements are needed for their crops.

2d. These analyses have checked frauds in the manufucture of fertilizers. They have improved the quality of those imported into the State-many say as much as 20 or 25 per eent.

$3 d$. They have exposed gross frands in some instances and enc. hled farmers to avoid being cheatcd by them.

4th. Such publieations and the very interesting reports of the Commissioner of Agriculture have, in North Carolina, as in Germany, France, England and several States of this Union, been the means of creating an intelligent interest in questions of agricul- 
tural chemistry, and spreading information about them among the people.

Farmers do not now buy fertilizcrs blindly at haphazard, but like they buy cloth, shoes, \&ce, with reference to the real value of the articles and their suitalility to their needs. They try cxperiments more than formerly, observing more accurately the effects on the crops.

5th. The home manufacture of fertilizers has been stimulated. Many farmers do not buy the manufactured article at all, but they purchase the chemicals at first hands from importers and manufacture and mix for themselves, producing a mixture highly profitable, as they claim, at much less cost.

6th. The tax on fertilizers is pronounced to be the best mode of sustaining the I partment of Agriculture and its work, including not only the analysis of fertilizers, but all the important subjects which it has in charge under the able conduct of the Board of Agriculture. Abundant evidence is at hand to prove that the price of fertilizers has not been raised by the tax. Companies are able to sell here at the same rate as in other States, and they sell an article of known value.

7th. At the same time the committee report that the dissatisfaction at first expresed by some of the manufacturers has mostly died out. Many of them like the plan of having analyses made, as it sares them from the competition of dishonest and inferior articles. The only injury the best grades have suffered has been from the increased home mixture of chemicals, by the furmers. But this the committee think a desirable thing for our State.

The committee sincerely hope that so far from abolishing the tax, the Ceneral Assembly might, with advantage to the State, grant increased means of usefulness to the Board of Agriculture. Certainly no legislation in their remembrance has 
been of such direct value to the agricultural interests, on which chicfly the prosperity of our state depends.

Respectfuily submitter,

\author{
J. R. Hetchins, \\ Bryan Grimes, \\ Peter E. Sumth, \\ R. B. Cal.dWell, \\ JO:EPH A. WORTH, \\ Committec.
}

November 2 ?th, 157 S.

[Correspondence of the Farmer and Hechanic.]

The Aaricleturat Experment Station.

It seems that nothing can be done for the farming interest which is not assiiled. We are not of those who account it impudence to assil the wistom of public mell or public measures. People honestly differ in their opinions, and every citizen has a right to challenge the wislom of institutions designed for the public goror, and supported from the public purse. Still it seems that a fatality attends every measure which is legislated in the interest of the farmer. The Farmer and Mrchanic attacks the Agricultural Department in its management and expenditures, and perhaps justly, but it allows a little word of commendation of the Experiment Station, which the most intelligent farmers of my acruaintance judge to be of incalculable benefit to them. Their conclusion seems to be well founded.

The old and thickly-settled countries of Europe, whose prosperity is closely and largely dependent upon the successful cultivation of the soil, have proved Experiment Stations a necessity. Witness the number established in those countries. 
The establishment of such Stations is, the world over, accounted an evidence of progress, and North Carolina (once Pip Van Winkle), with Connecticut, is now generally recognized as in the van of improvement.

Before the institution of our Station the North Carolina farmers were annually bled of their hard-earned cash to pay for so-called fertilizers, containing a large percentage of sand.

THE FARMERS NOW ALMOST UNANIMOUSLY TESTIEY THAT THE QUALITY HAS GREATLY IMPROVED, AND THE PRICE HAS FALLFN.

This fall in price is fully as great in North Carolina as in other States which have $n o$ control stations. This protection afforded the farmer costs him nothing.

There are forty-two brauds sold in the State. Does this look like a monopoly? There were $10 \mathrm{~s}$ brands before the establishment of the Station. Why should there be less now, if they have learned how to manipulate and impose inferior articles on the farmers with as large a profit as formerly?

Chemical analyses never yet pretended to dictate to your Johnston county correspondent, nor any other, what his farm needs; nor does it prevent his still using the ingredients suited to his soil. It does tell him where he can get them, and get them cheapest, and guaranteed against adulteration. The law does drive frauds out of the State. Your less experienced farmers are they who most need this protection. The Station protects against spurious seed likewise.

For one, I beg to be excused the necessity of relying wholly on field experiments to test the value of a fertilizer. It is rather costly at forty dollars per ton, and a life-time of experiments to find a good article, which, without protection, may be adulterated as soon as its reputation is made. 
The tests of '7s are good for '79. It is not likely that the penalty of the law will be incurred. Dr. Ledoux has shown that his tests cannot be published sooner than they are, in time for grain crops. Is procured, the samples are safe and genuine.

The writer of this is in no way comnected with the Department, and certainly is not in the interest of the trade No farmer can rearl Dr. Ledoux's report without being impressed with the immense value to him personally of the Station, and that the improvement in fertilizers, as shown by his crops, is due thereto. To abandon the Experiment station is to rob the farmer.

P.

[Mrs. Mary Bayarl clarke, in Jale: - Wedily.]

Axyel Repret of the N. C. Agrifultural ExperiMENT STATIOY FOR 1879.

The gromed-swell from the waves of the storm of retrenchment brewed in that big tea-cup, our last Legislature, may possibly toss this book back and forth as the wind of its eloquence did the report of our State Geologist; for every North Carolinian who is called on, either directly or indirectly, to vote away " the people's money," in ariably, before doing so, asks himself and everybody else-"cui bono?"what's the use? Without the slightest desire to interfere with the rights of man, we do must earnestly hope that Professor Ledoux's book will be read before the penny-wise and pound-foolish demon of stinginess, in the plausible disguise of economy, again gets loose in North Carolina.

He tells us on the first page that " to be in any measure a master of the science of Agriculture, a man must be at once a hotanist, chemist, geologist and meteorologist." With this appalling necessity before us, we shall not attempt to go into the scientific merits of the book, but take only the com- 
mon-sense view of it; and in this light most unhesitatingly pronounce it an interesting and instructive volume, not only for the farmer, but for his wife and daughter. But what good does a State Experiment Station do the farmers of North Carolina? The answer to this question depends in a great measure on the farmers themselyes. Professor Ledoux tells them very plainly what good it may do them, if they will avail themselves of it.

1st. It offers them complete and free protection against frauds in commercial fertilizers, chemicals and seed.

2d. It gives them free analyses of ores, soils, marls, mine* rals and mineral waters.

$3 \mathrm{~d}$. It investigates all subjects of agricultural interest, and furnishes a place where every farmer and his wife can send for solution questions and problems which meet them in following their calling, and which require chemical or other scientific knowledge.

Take one instance for example from the detailed report: "There are factories in Europe where seed of various kind, are manufactured out of quartz. The quartz is ground and sieved and stained with various dyes to imitate almost exactly in size and color almost any kind of seed, especially clover." These artificial seed are sold at $\$ 3.50 \mathrm{a} c w t$, and as many as fifteen tons have been purchased by one English house alone. Specimens of them are kept at the Station. and the most practised eye could not deteet a sample of clover seed adulterated with them as high as 25 per cent. Then, too, the seed of worthless grasses, poisonoug plants and weeds are often sold for opchard grass, red clover, and other valuable grass seed, and to detect these impositions there are at the Station a thousand specimens of seed arranged in glass tubes by means of which nearly all seeds sent for test can be at once identified and the impurities named. The history of the analysis of the "Vitative Compound" will suffice as an example of what benefit a farmer may derive from the Station in the use of commercial fer- 
tilizers. A sample of this "compound," put up in pretty little boxes holding about two ounces, and sold for the mod. erate sum of $\$ 1.00$ a box, was sent to Professor Ledoux. The proprietor claimed for it that it would not only destroy insects or parasitic enemies, but would protect seed from birds, and contained in a condensed form those ingredients, so generally deficiest in the soil, and yet so essential to the immediate germination and rapid growth of the plant. On examination, the so called fertilizer was found to contain neither phosphoric acid, ammonia, nor potash, but lead and zinc, each a violent poison; acetate of lead, worth at retail about twenty-five cents a pound, and sulphate of zinc worth about ten cents a pound. Three things were settled beyond a doubt by this analysis. First, the "Vitative Compound" has no fertilizing properties whatever; Second, it costs twenty-four times as much as it is worth; Third, it is most decidedly "poisonous to animals," as the circular says.

In the history of artificial fertilizers we have a most in. teresting account of the first use of bone dust as such, as early as the middle of the first century, when Caracteous, king of South Wales, was warring against the Romans, and collecter their bones in heaps, which were afterwards spread on the soil and produced wonderful crops of wheat, barley and other grain for many years. But there is one advan. tage in the use of bone dust now, which Prof. Ledoux does not mention, and probably never heard of. A lady of our acquaintance discovered it shortly after the war, when a report was circulated that the Federals were collecting soldiers' bones and sending them North to be ground for manure. Missing her roasting ears every morning she coolly informed some of her darkie neighbors that she had got some Yankee bone dust for her field, because it was well known that spirits would haunt the place where their bones were laid, and all persons going into that patch after dark might look out for ghosts. "Dat's so," replied an old daddy. "Ghosteses 
will follow dey bones mistis, and nn mistake." From that dity she never missed a roasting ear.

Even the ehildren are not forgotten by the Station, for we have an analysis of candy, and have not a doubt hut that we might obtain one of hair dye and smuff for the middle aged, and rouge and pearl pouder for the young ladies. In short the Report is a family book suggestive of many things and useful to the house-keeper as well as the firmer.

[Chapel Hill Iedger, October, 1879.]

The Annual Repoit of the North Carolina Agricultural Experiment Station is before us. The report is somewhat voluminous-containing 198 pages and giving an arcount of the Station from its foundation to the present time. Dr. Ledoux in his preface says that "the report is intended to be useful to our farmers, as far as possible, hence many explanations and forms of expression are adopted which may seem useless to scientific readers." "This is one of the ehief merits of the report. It is a stright forwarl, plain state. ment of the work which the department lias performed, of what ought to be done, of enquiries, of replies, and in short, is a complete setting forth of what has been done by the Station. The report furnishes information which the farmers of the State have desired. It tells them many valuable truths about grasses, seeds, waters, manures, guanos, and other things of much practical importance. The report shows that Dr. Ledoux is not only aequainted with the needs of our people in an agricultural point of view, but takes an active interest in pointing out to them ways in which those needs may be supplied. No possible State agricultural industry but that it claims his attention and study - the sugar beet, the Irish potato and the manufacture therefrom of starch and glucose, the use of refuse fish as a fertilizer, the quick manufacture of vinegar, eotton seed oil 
mills, the manufacture of sassafras oil, and many other things. Throughout the report there is a frankness of statement which wins the reader and a confident tone of succuss which seems to spring from a conscionsness of a good cause and a knowledge of duty performed, and encourages ono to hope for a brighter future for North Carolina. I'pon the whole we find the report very good reading-far above the average of such reports-and containing much which wonld benefit any man in the State.

We bid Dr. Ledoux and the Siate Board of Agriculture Crod speed in their noble work. We append what Dr. L. says of fertilizers in North Carolina before and since the em tablishment of the Control Station:

"IN 1876, BEFORE THE LAW P'AOYIDING ROL FERTILALA: (WNTROL WAS PASSED, TIERE WERE $10 S$ BRANDS OF FERTILIZERS SOLD IX North CAROLINA. SOME OF THEM WEIR MISEAABLE STUFE, OTHEF DOWYRIGHT SWINULES. ONF ESPECIALLX, WITH A LARGE SALE, WAS FUUND TO CONTAIX (j) PER CENT. OF SANT, ANT OTHERS SO POOR THAT THE) WERE CONDEMNED IN GEORGLA, WERE RE-SHIPPED ANU SOLD IN North Carofina. AT l'Resent Therl Are but 42 liRANDS WHICH ARE LEGALLY ON AALE IN NoRTH CAROLINA: AND IT GIVES IL I'LASURE TO STATE THAT AMONG TIEN! ARE THE VERY BEST BRANIS FULNA IN THE TYITE1, STATE, IND NO S'TATE HAS NOW A MORE COMlLETE l'DUTECTION FOR ITS FARIIERS, ANU NO S'TATE BETTER PROTECTS IEALERS IX FERTILIZERS FROM HAVING TO (WMPETE WITH FRAUIULEXT MANUFACTIRERS THAN UUR OWX. THREE THINGS ARE CERTAIN ANU ADMIT OF PROOF: 1ST, 'THAT EERTILIZERS ARL ('HEAPER IN NORTH CAROLINA TU-I)AY THAN THEY WERF BEFORE THE TAX WAS IMPOSEL. ZL, THAT THEY ARE BET'TER ON AN AVERAGE. 3I, 'THAT THEY ARE AS CHEAl IN

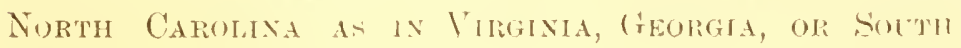


CAROLINA, DUE ALLUWANCE BEING MADE FUR INCREASE OR DECREASE OF FREIGHT, "WING TO DISTAXCE.

(Col. J. D. Cameron.)

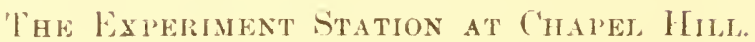

This is the first established in the south, the second in the United States; and it is pleasant to hear that it is growing stealily in the favor of farmers. Prof. Ledoux receives hundreds of letters for information, not only in relation to the analysis of soils, in relation to the value of seeds, the utility of new plants, but also in relation to other mat. ters of interest to the farmer, all of which he answers promptly, as he should do, in view of the important relation in which the station stands to agriculture. 





\section{THE NORTH CAROLINA State Experiment Station.}

THE ADVANTAGES IT OFFERS TO

\section{FARMERS AND OTHERS.}

1. Free analyses of all ('hemicals used in Composting, provided the sender seeures the samples according to printed instructions fumished by the sitation, and prepays the express charges.

2. Free analyses of all Fertilizers legally on sale in the state, provicted the samples are seeured by an authorized agent of the Department of Agriculture or after correspondence with the Director.

3. Free analyses of all Well Waters, articles of Food atnd Drugs, Disinfectants, se., when the analyses are desired for sanitary puposes, the permission of the secretary of the state Board of Health is secured, and the express charges on the sample are prepaid.

4. Free analyses and exantination in all cases of 1 robable Poisoning when the suspected aricle is sent acording to printed instruction, and by order of Coromers and County superintendents of llealth.

5. Free analyses of Marls when desired by farmer's.

6. Free analyses of Mineral Waters when sent with the permission of the state Geologist. and the express charges aro prepaid.

7. Free identifieation and qualitative analyses of all Minerals and ores. For a conplete or quantitative analysis the permission of the state (ieologist inust be obtitined.

8. Free tests of the gemuinating or sproutlug capacity of all Seeds of grains, grasses, flowers or vegetables, with a report as to their purity, and identifiention of any weed or uther foreign seeds present. Seect samples are best sent by mail.

9. Free identification of useful or injurious Grasses.

10. Free identification of Insects injurious to Vegetation, and reports upon the best means of lestroying them.

11. Correspondence will he promptly atterded to upon all subjects.tireetly or indirectly related to Agriculture.

12. Printed reports will be mailed free of cliarge npon reguest upon the following subjects: Inrections for composting; formulats for different soils and crops; analyses of chemicals and fertilizers legally on sale in Nolth Carolina; directions for utilizing bones; for making vinegar; for growing sugar-beet; upon drinking waters; the valne of pine straw; the history, nse and value of the eow-pea; the composition of marls and solls; the extrpction of sassafrats oil ; the history and use of art ifielal manures, \&e., der.

The Experiment station having been fulls equipped by order of the Bond of Agriculture, for the prosecution of the varions branches of work above mentioned, our farmers are urgently recuested to avail themselves, af these advantages. Address all letters to

\section{The N. C. Agriculttral Experimenlt Station,}

CHAPEL HILL, N. C. 

LIBRARY OF CONGRESS

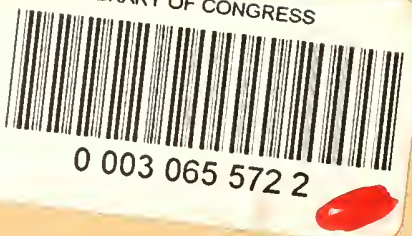

